J. AMER. SOC. Hort. SCI. 115(6):884-887. 1990.

\title{
Yield of Successively Cropped Polyethylene- mulched Vegetables as Affected by Irrigation Method and Fertilization Management
}

\author{
G.H. Clough' and S.J. Locascio \\ Vegetable Crops Department, Institute of Food and Agricultural Sciences, University of Florida, \\ Gainesville, FL 32611
}

S.M. Olson

North Florida Research and Education Center, Institute of Food and Agricultural Sciences; University of Florida, Quincy, FL 32351

Additional index words. Brassica oleracea, Cucurbita pepo, Lycopersicon esculentum, broccoli, squash, tomato

\begin{abstract}
Broccoli (Brassica oleracea L. var. italica), followed by tomato (Lycopersicon esculentum Mill) or squash (Cucurbita pepo L. var. melopepo), and then broccoli were produced in succession re-using the same polyethylenemulched beds at two locations with different soil types. First-crop broccoli yield was earlier and greater with drip than with overhead irrigation and increased as N-K rate increased from 135-202 to $270-404 \mathrm{~kg}^{-h^{-1}}$. On a tine sandy soil, yields of second and third crops produced with residual or concurrent fertilization increased with an increase in $\mathrm{N}-\mathrm{K}$ rate. On a loamy fine sandy soil, yields also increased as the rate of residual N-K increased; yields of second and third crops did not respond to rate of concurrently applied $\mathrm{N}-\mathrm{K}$, but were higher with concurrent than with residual fertilization, except total tomato yields were similar with either application time. With drip irrigation and concurrent weekly fertigation, yields equalled or exceeded those obtained with preplant fertilization and overhead irrigation.
\end{abstract}

hile the value of irrigation or mulch in the production of vegetable crops has been well documented, irrigation and mulch, when used together, can greatly increase yields over either alone (BheIla, 1988; Emmert, 1957; Locascio and Myers, 1974). Drip irrigation, in addition, permits supplemental fertilizer applications to mulched crops, greatly increasing the feasibility of using an irrigated mulch production system for multiple crops and seasons (Stall et al., 1977).

A production system for successive cropping, re-using polyethylene-mulched beds with drip or overhead irrigation, may reduce costs and energy use per unit of production for vegetable growers by more complete or extended utilization of inputs. Brown et al. (1985) illustrated the economic advantages possible with vegetable double-cropping, although their results were limited due to a relatively short production season.

Bryan and Dalton (1974) demonstrated a sequential crop system for overhead sprinkler-irrigated tomato, whereby the second crop used the polyethylene mulch and fertilizer residues from the first to reduce second crop production costs. Second crop yields increased with refertilization, as compared to production with residual nutrients only. Other results for second crop response to fertilization rates and methods have been contradictory (Csizinszky et al., 1985; Shaw et al., 1978). Little information is available concerning use of polyethylene mulch after a second crop, although the testing of such a practice has been reported (Hayslip et al., 1978), but with few details.

Our study was conducted to determine the feasibility of using the same full-bed polyethylene mulch for sequential vegetable production and to examine the effects of production practices for successive cropping on vegetable yields.

Received for publication 26 Jan. 1990. Florida Agricultural Experiment Stations Journal Series no. R-00433. The cost of publishing this paper was defrayed in part by the payment of page charges. Under postal regulations, this paper therefore must be hereby marked advertisement solely to indicate this fact.

'Present address: Dept. of Horticulture, Oregon State Univ., Hermiston Agricultural Research and Extension Center, Box 105, Hermiston, OR 97838.

\section{Materials and Methods}

Broccoli, followed by tomato or squash, and then broccoli was produced in succession at two northern Florida locations in 1983 and 1984 with overhead or drip irrigation. Crops were produced with either concurrent application of $\mathrm{N}-\mathrm{K}$ fertilizer at 135-202 or 270-404 $\mathrm{kg} \cdot \mathrm{ha}^{-1}$ or with residual fertilizer from the previous crop. The experimental design for the 1983 broccoli crop was a split-split plot, with location as main plots, irrigation method as sub-plots, and N-K rate as sub-sub-plots. Treatments were replicated eight times. In Spring 1984, the fall plots were subdivided, and tomato and squash crops were produced in a split-split plot design experiment with four replications. Treatments were similar to those applied to the previous broccoli crop, but only one-half of the spring plots was refertilized; the second half was grown with residual fertilizer from the fall. The subsequent Fall 1984 broccoli crop experimental design was similar, a split-split plot design with four replications and with the effect of the previous squash or tomato crop on broccoli yield examined as an additional experimental factor. Plots that did not receive fertilizer in the spring were refertilized, while those that had been fertilized in the spring were not, and the broccoli on those plots was produced with residual fertilizer from the spring tomato or squash crop.

The soil at Gainesville, Fla., was a fine sand (loamy, siliceous hyperthermic, Grossarenic Palendult), and at Quincy, Fla., the soil was a loamy fine sand (fine-loamy, siliceous, thermic, Typic Palendult).

Plant beds $18 \mathrm{~m}$ long and $1.8 \mathrm{~m}$ apart were formed with a 1m-wide bed press. All plots received $112 \mathrm{~kg} \mathrm{P} / \mathrm{ha}$ as triple superphosphate and $33.6 \mathrm{~kg}$ complete commercial micronutrient $\mathrm{mix} / \mathrm{ha}$ in 1983. At bedding, overhead-irrigated plots received $100 \%$ and drip-irrigated plots received $40 \%$ of the treatment $\mathrm{N}$ and $\mathrm{K}$ as $\mathrm{NH}_{4} \mathrm{NO}_{3}$ and $\mathrm{KCl}$ In a once-over operation, the fertilizers were rototilled into the top $15 \mathrm{~cm}$ of the plant beds, methyl bromide-chloropicrin was injected at $450 \mathrm{~kg} \cdot \mathrm{ha}^{-1}$, a single biwall drip irrigation line with emitters spaced $30 \mathrm{~cm}$ apart was centered on the top of the drip-irrigated beds, and beds 
were covered with $0.064 \mathrm{~mm}$ of black polyethylene mulch. Onemonth-old 'Emperor' broccoli transplants were set $30 \mathrm{~cm}$ apart in two rows/bed, $60 \mathrm{~cm}$ between rows $(36,000$ plants/ha), in Sept. 1983. The remaining $60 \%$ of the treatment $\mathrm{N}$ and $\mathrm{K}$ was injected weekly through the drip irrigation system over 9 weeks.

Marketable central heads from the interior $15 \mathrm{~m}$ of each plot were harvested five times over 3 weeks at each location. Yield data were combined as early (harvest $1+2+3$ ), late (harvest $4+5$ ), and total (early + late) for analysis of variance.

In the spring, on one-half of the mulched rows, 'Dixie' yellow squash was direct-seeded into the same holes used for the previous fall broccoli crop. On, the other half, one-month-old 'Sunny' tomatoes were transplanted $45 \mathrm{~cm}$ apart in a single row $15 \mathrm{~cm}$ from the bed center. Overhead-irrigated, concurrently fertilized plots received $100 \%$ of the treatment $\mathrm{N}-\mathrm{K}$ as $\mathrm{NH}_{4} \mathrm{NO}_{3}$ and $\mathrm{KCl}$ applied by hand through holes $30 \mathrm{~cm}$ apart in the bed center at the time of crop establishment. Drip-irrigated plots were fertilized through the irrigation system, beginning 1 week after crop establishment and continuing for 12 weeks.

Harvest of the pruned, staked tomato crop began 12 weeks after transplanting and continued for 6 weeks. Squash fruit were harvested every 2 to 3 days, beginning 5 weeks after emergence and continuing for 6 weeks.

In Sept. 1984, overhead-irrigated, residual-fertilizer spring plots were refertilized as previously described, while concurrently fertilized spring crop plots received no fertilizer. Dripirrigated plots received the same nutrients in the irrigation water in nine weekly applications. Broccoli transplants were set as described for the 1983 crop.

Irrigation was applied two to three times weekly to overheadirrigated plots in an amount equal to pan evaporation $\left(\mathrm{ET}_{\mathrm{pan}}\right)$, as measured with a U.S. Weather Bureau class A evaporation pan at each site. Drip irrigation was applied daily to the entire plot area in an amount equal to $0.55 \mathrm{ET}_{\mathrm{pan}}$, based on the average daily $\mathrm{ET}_{\text {pan }}$ for the previous 10 days (the mulched, raised bed area received water in an amount equal to $\left.\mathrm{ET}_{\mathrm{pan}}\right)$. The quantity of water applied for each irrigation treatment was reduced to compensate for rainfall since the previous irrigation application. Recommended commercial production practices were followed for all crops.

\section{Results and Discussion}

In 1983, early and total broccoli yields were higher at Quincy than at Gainesville and with drip than with overhead irrigation (Table 1). Average head weight was higher at Quincy than Gainesville., but was not affected by irrigation method. High temperatures after transplanting at Gainesville may have caused the location effect. Late and total yields increased with an increase in $\mathrm{N}-\mathrm{K}$ rate, but head weight was not affected.

On the sandy soil at Gainesville, yield of large tomato fruit was higher with overhead than with drip irrigation and increased with an increase in $\mathrm{N}-\mathrm{K}$ rate (Table 2). Yield of smaller-sized fruit and total yield was unaffected by irrigation method and $\mathrm{N}-\mathrm{K}$ rate. Yield was much higher with concurrent than with residual fertilization. Higher tomato yields have been obtained with drip than with overhead irrigation (Locascio and Myers, 1974; Stall and Bryan, 1975), but the opposite effect has been reported due to leaching of soil nutrients by drip irrigation (Persaud et al., 1976). Concurrently fertilized drip-irrigated tomato yields may have been reduced as a result of $\mathrm{N}-\mathrm{K}$ application timing also. All $\mathrm{N}-\mathrm{K}$ was applied preplant to overhead-irrigated plots, but was applied in weekly increments starting 1 week after transplanting to drip-irrigated plots. Others have obtained
Table 1. Broccoli yield as affected by location, irrigation method, and N-K rate, 1983.

\begin{tabular}{lcccc}
\hline \hline & \multicolumn{3}{c}{ Yield (t-ha-') } & Head \\
\cline { 2 - 4 } Treatment & Early & Late & Total & Wt (g) \\
\hline Location & & & & \\
$\quad$ Gainesville & 2.7 & 3.5 & 6.2 & 235 \\
Quincy & 4.2 & 3.8 & 8.0 & 319 \\
& $* *$ & NS & $* *$ & $* * *$ \\
Irrigation & & & & \\
$\quad$ Overhead & 2.7 & 3.8 & 6.5 & 269 \\
Drip & 4.2 & 3.5 & 7.7 & 284 \\
N-K (kg-ha-1) & $* * *$ & NS & $* * *$ & NS \\
135-202 & 3.6 & 3.3 & 6.9 & 264 \\
$270-404$ & 3.3 & 4.1 & 7.4 & 290 \\
& NS & $* * *$ & $* *$ & NS \\
\hline
\end{tabular}

$\overline{\mathrm{NS}},{ }^{* *}, * * *$ Nonsignificant or significant at $P=0.01$ or 0.001 , respectively.

Table 2. Tomato yield as affected by irrigation method and rate and time of N-K application, Gainesville, Fla., 1984.

\begin{tabular}{|c|c|c|c|c|}
\hline \multirow[b]{2}{*}{ Treatment } & \multicolumn{3}{|c|}{ Marketable fruit $\left(\mathrm{t} \cdot \mathrm{ha}^{-1}\right)^{\mathrm{z}}$} & \multirow[b]{2}{*}{ Tota } \\
\hline & Large & Medium & Small & \\
\hline \multicolumn{5}{|l|}{ Irrigation } \\
\hline Overhead & 15.9 & 10.6 & 4.1 & 30.6 \\
\hline Drip & 13.8 & 8.8 & 3.9 & 26.5 \\
\hline \multicolumn{5}{|l|}{$\mathrm{N}-\mathrm{K}\left(\mathrm{kg} \cdot \mathrm{ha}^{-1}\right)$} \\
\hline $135-202$ & 12.5 & 8.9 & 4.0 & 25.4 \\
\hline $270-404$ & 17.2 & 10.5 & 4.0 & 31.7 \\
\hline \multicolumn{5}{|l|}{$\mathrm{N}-\mathrm{K}$ time } \\
\hline Residual & 7.3 & 6.1 & 3.0 & 16.4 \\
\hline Concurrent & 22.4 & 13.3 & $\begin{array}{l}5.0 \\
* * *\end{array}$ & 40.7 \\
\hline
\end{tabular}

${ }^{7}$ Mean fruit weights for sizes were: large $=205 \mathrm{~g}$, medium $=150 \mathrm{~g}$, and small $<115 \mathrm{~g}$.

$\mathrm{NS}, * * * *$ Nonsignificant or significant at $P=0.05$ or 0.001 , respectively.

highest yields of drip-irrigated tomatoes with all or part of the nutrients applied before planting (Locascio et al., 1989). At Quincy, tomato yields also were higher with overhead than with drip irrigation (Table 3). The lower yield with drip irrigation resulted, in part, from infestation with Sclerotinia sclerotiorum (Lib) de Bary. The severe incidence of this pest in the dripirrigated plots was due to the high soil moisture levels maintained by drip, compounded by heavy rains and poor drainage of the heavier soil. The heavy rains near harvest also resulted in many split fruit, greatly increasing the proportion of cull tomatoes obtained with each irrigation method. Leaching of soil nutrients with drip irrigation may have been a factor as well. Yield was not affected by either application rate or time, but the two treatments interacted to affect fruit yield (Table 4).

With the lower $\mathrm{N}-\mathrm{K}$ rate, both weight and number of marketable fruit were higher with concurrent than with residual fertilizer application. With the higher application rate, fruit weight and number were similar when tomatoes were grown with either residual or concurrent fertilization. Apparently, on the heavier soils, with fall fertilization at a high rate, adequate quantities of residual fertilizer remained to produce a spring tomato crop without further fertilization.

All treatment factors interacted to affect yield of squash grown 
Table 3. Tomato yield as affected by irrigation method and rate and time of N-K application, Quincy, Fla., 1984.

\begin{tabular}{|c|c|c|c|c|}
\hline \multirow[b]{3}{*}{ Treatment } & \multicolumn{4}{|c|}{ Yield } \\
\hline & \multicolumn{2}{|c|}{ Marketable } & \multicolumn{2}{|c|}{ Cull } \\
\hline & $\begin{array}{c}W t \\
\left(t \cdot h a^{-1}\right)\end{array}$ & $\begin{array}{c}\text { No. } \\
(1000 / \mathrm{ha})\end{array}$ & $\begin{array}{c}W t \\
\left(t \cdot h a^{-1}\right)\end{array}$ & $\begin{array}{c}\text { No. } \\
(1000 / \mathrm{ha}) \\
\end{array}$ \\
\hline \multicolumn{5}{|l|}{ Irrigation } \\
\hline Overhead & 11.3 & 55.0 & 46.7 & 286 \\
\hline \multirow[t]{2}{*}{ Drip } & 5.9 & 28.7 & 25.3 & 161 \\
\hline & & & & $* *$ \\
\hline \multicolumn{5}{|l|}{$\mathrm{N}-\mathrm{K}\left(\mathrm{kg} \cdot \mathrm{ha}^{-1}\right)$} \\
\hline $135-202$ & 8.7 & 43.2 & 33.8 & 213 \\
\hline \multirow[t]{2}{*}{$270-404$} & 8.4 & 40.5 & 38.2 & 234 \\
\hline & NS & NS & NS & NS \\
\hline \multicolumn{5}{|l|}{$\mathrm{N}-\mathrm{K}$ time } \\
\hline Residual & 7.4 & 36.0 & 31.0 & 192 \\
\hline \multirow[t]{2}{*}{ Concurrent } & 9.7 & 47.7 & 40.9 & 255 \\
\hline & NS & NS & NS & NS \\
\hline Rate $\times$ time & $*$ & $*$ & NS & NS \\
\hline \multicolumn{5}{|c|}{ Ns,*,** Nonsignificant or significant at $P=0.05$ or 0.01 , respectively. } \\
\hline \multicolumn{5}{|c|}{$\begin{array}{l}\text { Table } 4 \text {. Marketable tomato yield as affected by interaction of N-K } \\
\text { rate and N-K application time, Quincy, Fla., } 1984 \text {. }\end{array}$} \\
\hline & \multicolumn{4}{|c|}{$\mathrm{N}-\mathrm{K}\left(\mathrm{kg} \cdot \mathrm{ha}^{-1}\right)$} \\
\hline & $135-202$ & $270-404$ & $135-202$ & $270-404$ \\
\hline \multirow{2}{*}{$\begin{array}{c}\mathrm{N}-\mathrm{K} \\
\text { application } \\
\text { time }\end{array}$} & \multicolumn{4}{|c|}{ Yield } \\
\hline & \multicolumn{2}{|c|}{$\begin{array}{c}\text { Wt } \\
\left(\mathrm{t} \cdot \mathrm{ha}^{-1}\right)\end{array}$} & \multicolumn{2}{|c|}{$\begin{array}{l}\text { No. } \\
1000 / \mathrm{ha})\end{array}$} \\
\hline Residual & 5.2 & 9.6 & 26.0 & 46.0 \\
\hline \multirow[t]{2}{*}{ Concurrent } & 12.2 & 7.2 & 60.4 & 35.0 \\
\hline & & NS & $*$ & NS \\
\hline
\end{tabular}

${ }^{\mathrm{Ns}}, *$ Nonsignificant or significant at $\mathrm{P}=0.05$, respectively.

Table5. Squash yield as affected by interaction of location, irrigation method, N-K rate, and N-K source.

\begin{tabular}{|c|c|c|c|c|}
\hline \multirow{3}{*}{$\begin{array}{c}\text { Irrigation } \\
\text { method } \\
\text { and } \mathrm{N}-\mathrm{K} \text { rate } \\
\left(\mathrm{kg} \cdot \mathrm{ha}^{-1}\right)\end{array}$} & \multicolumn{4}{|c|}{ Location and $\mathrm{N}-\mathrm{K}$ source } \\
\hline & \multicolumn{2}{|c|}{ Gainesville } & \multicolumn{2}{|c|}{ Quincy } \\
\hline & $\overline{\text { Residual }}$ & Concurrent & Residual & Concurrent \\
\hline Overhead & \multicolumn{4}{|c|}{ Yield $\left(t \cdot h a^{-1}\right)$} \\
\hline $135-202$ & 6.0 & 38.1 & 13.2 & 38.6 \\
\hline $270-404$ & 28.5 & 45.0 & 20.8 & 34.8 \\
\hline & $* * *$ & $*$ & NS & NS \\
\hline \multicolumn{5}{|l|}{ Drip $\quad \cdot$} \\
\hline $135-202$ & 6.0 & 42.6 & 3.7 & 39.7 \\
\hline $270-404$ & 12.3 & 48.1 & 15.1 & 34.7 \\
\hline & $* *$ & NS & $* *$ & NS \\
\hline
\end{tabular}

Ns, ${ }^{*}, * *, * *$ Nonsignificant or significant at $P=0.05,0.01$, or 0.001 , respectively.

as a second crop in Spring 1984 (Table 5). At Gainesville, squash yields were very low when produced with residual fertilization applied at the 135-202 kg-hal rate. With both overhead and drip irrigation, yields increased significantly when fall fertilizer rate increased. With concurrent fertilizer application, however, yield increased with application rate only with overhead irrigation; similar high yields were obtained with either fertilization rate with drip irrigation. At Quincy, squash yield increased with $\mathrm{N}-\mathrm{K}$ rate only with drip irrigation and residual fertilization. A similar lack of response to increasing concurrent
Table 6. Broccoli yield as affected by interaction of irrigation method, N-K rate, N-K time, and crop sequence, Gainesville, Fla., 1984.

\begin{tabular}{|c|c|c|c|c|}
\hline \multirow{3}{*}{$\begin{array}{c}\mathrm{N}-\mathrm{K} \text { application } \\
\text { time and } \\
\text { rate } \\
\left(\mathrm{kg} \cdot \mathrm{ha}^{-1}\right) \\
\end{array}$} & \multicolumn{4}{|c|}{ Sequence $^{z}$ and irrigation } \\
\hline & \multicolumn{2}{|c|}{$\mathrm{Br}-\mathrm{Tm}-\mathrm{Br}$} & \multicolumn{2}{|c|}{$\mathrm{Br}-\mathrm{Sq}-\mathrm{Br}$} \\
\hline & Overhead & Drip & Overhead & Drip \\
\hline Residual & \multicolumn{4}{|c|}{ Yield $\left(t \cdot h a^{-1}\right)$} \\
\hline $135-202$ & 2.4 & 0.8 & 4.8 & 0.4 \\
\hline \multirow[t]{2}{*}{$270-404$} & 6.3 & 2.1 & 7.6 & 1.5 \\
\hline & $*$ & NS & $*$ & $*$ \\
\hline \multicolumn{5}{|l|}{ Concurrent } \\
\hline $135-202$ & 7.3 & 9.9 & 9.6 & 9.8 \\
\hline \multirow[t]{2}{*}{$270-404$} & 10.7 & 10.2 & 10.5 & 11.8 \\
\hline & $*$ & NS & NS & NS \\
\hline
\end{tabular}

${ }^{2} \mathrm{Br}$ : broccoli, Tm: tomato, Sq: squash.

Ns, *Nonsignificant or significant at $P=0.05$, respectively.

Table 7. Broccoli yield as affected by interaction of irrigation method, N-K rate, N-K time, and crop sequence, Quincy, Fla., 1984.

\begin{tabular}{|c|c|c|c|c|}
\hline \multirow{3}{*}{$\begin{array}{c}\mathrm{N}-\mathrm{K} \text { application } \\
\text { time and } \\
\text { rate } \\
\left(\mathrm{kg} \cdot \mathrm{ha}^{-1}\right)\end{array}$} & \multicolumn{4}{|c|}{ Sequence $^{z}$ and irrigation } \\
\hline & \multicolumn{2}{|c|}{$\mathrm{Br}-\mathrm{Tm}-\mathrm{Br}$} & \multicolumn{2}{|c|}{$\mathrm{Br}-\mathrm{Sq}-\mathrm{Br}$} \\
\hline & Overhead & Drip & Overhead & Drip \\
\hline Residual & \multicolumn{4}{|c|}{ Yield $\left(t \cdot h a^{-1}\right)$} \\
\hline $135-202$ & 4.8 & 3.9 & 4.9 & 2.4 \\
\hline \multirow[t]{2}{*}{$270-404$} & 3.6 & 5.6 & 7.1 & 5.8 \\
\hline & NS & NS & NS & $*$ \\
\hline \multicolumn{5}{|l|}{ Concurrent } \\
\hline $135-202$ & 12.9 & 11.2 & 10.5 & 11.3 \\
\hline \multirow[t]{2}{*}{$270-404$} & 9.0 & 12.3 & 10.3 & 12.9 \\
\hline & NS & NS & NS & $*$ \\
\hline
\end{tabular}

${ }^{2} \mathrm{Br}$ : broccoli, Tm: tomato, Sq: squash.

Ns, *Nonsignificant or significant at $P=0.05$, respectively.

fertilization rate for overhead-irrigated second-crop squash following strawberry was reported by Albregts and Howard (1985).

As with squash, all treatments interacted to affect yield of the second broccoli crop. At Gainesville, following tomato, broccoli yield increased with an increase in application rate for both concurrent and residual fertilization with overhead irrigation, but was not affected by application rate for either application time with drip irrigation (Table 6). Yield increased with rate of $\mathrm{N}-\mathrm{K}$ application to the previous squash crop with both irrigation methods; however, with concurrent fertilization, following squash, yield of fall broccoli was higher with the higher rate only with drip irrigation.

At Quincy, second-crop broccoli yields were not affected by application rate with any treatment following tomato nor with overhead irrigation following squash (Table 7). With drip irrigation, however, yields increased with an increase in N-K application rate with both residual and concurrent application times.

With all crops, and especially on the sandy soil, which had a low cation-exchange capacity, drip irrigation, when applied at a rate equal to pan evaporation in the mulched-bed area, apparently leached nutrients and reduced potentially obtainable yields. Weekly fertigation partially overcame this problem, but application of nutrients earlier in the season may further improve yields, as might a reduction in water application rate. On the heavier soil, the effect was not as pronounced, probably due to increased nutrient retention associated with the higher cationexchange capacity.

Gravimetrically determined soil water, sampled daily for several days at Gainesville before irrigation application, was higher 
at the bed center than side and decreased with an increase in depth to $0.3 \mathrm{~m}$ with both irrigation methods (Table 8). With overhead irrigation, soil moisture increased with irrigation application, then decreased rapidly. At all locations and depths sampled, drip irrigation maintained a higher and more constant level of soil moisture than did overhead.

Visual observations made at the conclusion of the field" experiments indicated that the polyethylene mulch and drip lines were in relatively good condition and might have been used for at least one more crop. Diagnostic nematode samples taken after each crop indicated that there was no build-up of any species of this pest following 15 months of continuous cropping.

Successive cropping of polyethylene-mulched vegetables with either drip , or overhead irrigation resulted in more complete use of mulch, fertilizer, fumigant, fuel, and labor, reduced mulch disposal, and is a viable alternative to producing only one vegetable crop per application of these resources. Water use was lower with drip than with overhead irrigation and apparently may be reduced further.

Fertilization and water management is more critical with drip, but with fertigation, drip-irrigated vegetable yields can equal or exceed those obtained with overhead irrigation.

Table 8. Soil water percentage as affected by bed location, depth, and irrigation method.

\begin{tabular}{|c|c|c|c|c|}
\hline \multirow{3}{*}{$\begin{array}{l}\text { Depth } \\
\text { (m) }\end{array}$} & \multicolumn{4}{|c|}{ Location and irrigation method } \\
\hline & \multicolumn{2}{|c|}{ Center } & \multicolumn{2}{|c|}{ Side } \\
\hline & Overhead & Drip & Overhead & Drip \\
\hline & \multicolumn{4}{|c|}{ Soil water (\%)' } \\
\hline $0.0-0.1$ & 5.29 & 7.50 & 4.39 & 4.85 \\
\hline $0.1-0.2$ & 5.83 & 8.51 & 5.29 & 6.22 \\
\hline \multirow[t]{2}{*}{$0.2-0.3$} & 6.69 & 9.58 & 6.46 & 7.23 \\
\hline & & & $\mathrm{L}^{* * *}$ & \\
\hline
\end{tabular}

${ }^{2}$ Effect of depth was linear (L) and significant at $P=0.01$.

\section{Literature Cited}

Albregts, E.E. and C.M. Howard. 1985. Double cropping strawberries with vegetables. Proc. Fla. State Hort Sot. 98:299-301.

Bhella, H.S. 1988. Tomato response to trickle irrigation and black polyethylene mulch. J. Amer. Soc. Hort. Sci. 113:543-546.

Brown, J. E., W.E. Splittstoesser, and J.M. Gerber. 1985. Production and economic returns of three vegetable double-cropping systems. J. Amer. Soc. Hort. Sci. 110:414-417.

Bryan, H.H. and J.D. Dalton. 1974. Yield responses of tomatoes and second cropped butternut squash to fertilizer rate and placement under plastic mulch on Rockdale soil. Proc. Fla. State Hort. Sot. $87: 159-174$.

Csizinszky, A. A., D.N. Maynard, G.J. Hochmuth P.R. Gilreath, and R.L. Mitchell. 1985. Liquid fertilization of squash and muskmelon grown as a second crop following muskmelon. Proc. Fla. State hort. Soc. 98:287-291.

Emmert, E.M. 1957. Black polyethylene for mulching vegetables. Proc. Amer. Soc. Hort. Sci. 69:464-469.

Hayslip, N. C., J.W. Mishoe, and R.M. Sonoda. 1978. Methods of fumigation and fertilization between successive crops in established plastic mulch covered beds. Proc. Fla. State Hort. Sot. 91 :313-316.

Locascio, S.J. and J.M. Myers. 1974. Tomato response to plug-mix, mulch and irrigation method. Proc. Fla. State Hort. Sot. 87:126130 .

Locascio, S. J., S.M. Olson, and F.M. Rhoads. 1989. Water quantity and time of $\mathrm{N}$ and $\mathrm{K}$ application for trickle-irrigated tomatoes. J. Amer. Soc. Hort. Sci. 114:265-268.

Persaud, N., S.J. Locascio, and C.M. Geraldson. 1976. Effect of rate and placement of nitrogen and potassium on yield of mulched tomatoes using different irrigation methods. Proc. Fla. State Hort. Sot. 89:135-138.

Shaw, L. N., H.H. Bryan, and J.W. Mishoe. 1978. Double cropping mulch covered beds. Proc. Nad. Agr. Plastics Congr. 14:222-226.

Stall, W.M. and H.H. Bryan. 1975. Effect of production area and irrigation methods on tomato yields in south Dade County during the 1974-75 season. Proc. Fla. State Hort. Soc. 88:225-227.

Stall, W. M., H.H. Bryan, and P.H. Everett. 1977. Commercial use of plastic mulch and drip irrigation on vegetables in south Florida. Proc. Intl. Agr. Plastics Congr. 372-377. 